OPEN ACCESS

Edited by:

Onder Alpdogan

Thomas Jefferson University,

United States

Reviewed by:

Alice Di Rocco,

Sapienza University of Rome, Italy

Garima Pandey,

Moffitt Cancer Center, United States

*Correspondence:

Bing Wu

bingwu69@163.com

Specialty section:

This article was submitted to Hematologic Malignancies,

a section of the journal

Frontiers in Oncology

Received: 30 June 2020

Accepted: 22 February 2021

Published: 17 March 2021

Citation:

Zhang Y, Liu W, Zhang X and Wu B (2021) Case Report: Primary NK/T Cell Lymphoma Nasal Type of the Colon With Multiple Intestinal Perforations.

Front. Oncol. 11:577939.

doi: 10.3389/fonc.2021.577939

\section{Case Report: Primary NK/T Cell Lymphoma Nasal Type of the Colon With Multiple Intestinal Perforations}

\author{
Yan Zhang ${ }^{1}$, Weiping Liu ${ }^{2}$, Xinyue Zhang $^{3}$ and Bing $W u^{1 *}$ \\ ${ }^{1}$ Department of Radiology, West China Hospital, Sichuan University, Chengdu, China, ${ }^{2}$ Department of Pathology, West \\ China Hospital, Sichuan University, Chengdu, China, ${ }^{3}$ Department of Nuclear Medicine, West China Hospital, Sichuan \\ University, Chengdu, China
}

Background: Extranodal NK/T cell lymphoma is a rare non-Hodgkin lymphoma mainly involving the upper aerodigestive tract, even rarer is primary extranasal disease involving the intestine. We present a case of primary intestinal NK/T cell lymphoma with diagnostic challenge, which eventually developed into multiple intestinal perforations.

Case Presentation: A 35-year-old man presented with diarrhea and recurrent fever. Abdominal CT revealed multi-segmental intestinal wall thickening. Colonoscopy showed multiple irregular ulcers in colon. During the hospitalization, the patient developed intestinal perforation and an emergency surgery was performed. The resected specimen showed multiple perforations of the colon. The surgical samples underwent pathological analysis, and a diagnosis of extranodal NK/T cell lymphoma nasal type was confirmed. After recovering from surgery, the patient started receiving chemotherapy and PD-1 monoclonal antibody. Fortunately, he was discharged after significant improvement in his general condition. Eleven months follow-up was uneventful.

Conclusion: Early diagnosis of primary intestinal NK/T cell lymphoma is frequently difficult. Most patients were definitely diagnosed only after surgical resection following complications, resulting in a poor prognosis. Therefore, doctors should maintain high suspicion of this malignancy for early diagnosis at an early stage clinically.

Keywords: Nk/t cell lymphoma, extranodal, perforation, non-Hodgkin lymphoma, Intestinal neoplasm

\section{BACKGROUND}

Extranodal NK/T cell lymphoma nasal type (ENKTL) is a subtype of non-Hodgkin lymphoma (NHL). It is an invasive lymphoma derived from NK cells or cytotoxic T cells, which is related to Epstein-Barr virus infection. ENKTL is more frequent in Asia, Mexico and Central or South America and more commonly affects males than females $(1,2)$. ENKTL mainly occurs in the nasal/paranasal area, intestinal involvement is rare. Incidence of primary large bowel lymphomas comprises only $0.2-0.6 \%$ of large bowel malignant tumors (3). Diffuse large B-cell lymphoma is the most common histologic subtype of NHL, with ENKTL of the large bowel being less frequent (4). The main complaints, colonoscopy and imaging findings of patients with ENKTL involving the colon are non-specific, and may be similar to many other benign and malignant lesions. Diagnosis depends on immunohistochemistry. In this paper, we describe a very rare case of ENKTL involving the colon with multiple intestinal perforations. 


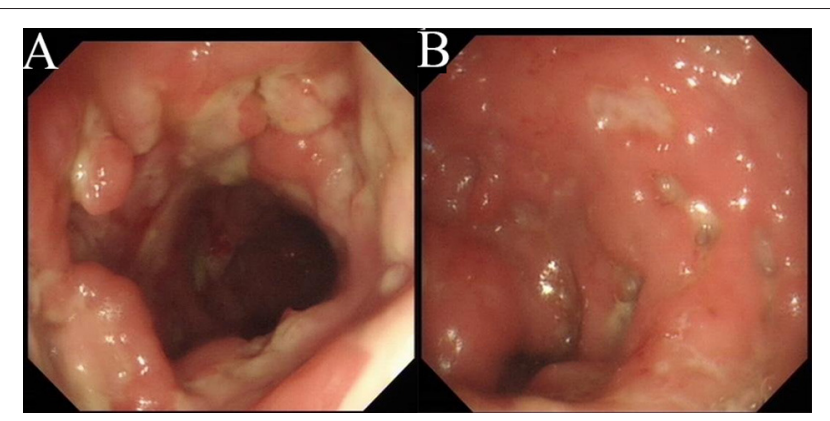

FIGURE 1 | Colonoscopy. There are multiple irregular ulcers in the colon. (A) Ascending colon. (B) Sigmoid colon.

\section{CASE PRESENTATION}

A 35-year-old male presented with diarrhea and abdominal pain after eating seafood and drinking 5 months before admission. The abdominal pain could be relieved after defecation. Two weeks later, he began to have a fever, up to $39.8^{\circ} \mathrm{C}$, accompanied by chills. He was admitted to the local hospital and broad spectrum antibacterial drugs were started empirically. Despite antibiotics, the fever continued to occur repeatedly, in peaks up to $41^{\circ} \mathrm{C}$, and the diarrhea persisted. Then the patient was suggested to be transferred to our institution.

Laboratory tests showed leukocytosis $\left(20.79 \times 10^{9} / \mathrm{L}\right)$, moderate anemia $(69 \mathrm{~g} / \mathrm{L})$, increased percent of neutrophils (91.6\%), increased C-reactive protein (CRP) $(80.90 \mathrm{mg} / \mathrm{L})$, procalcitonin (PCT) $(5.87 \mathrm{ng} / \mathrm{ml})$ and erythrocyte sedimentation rate (ESR) $(106.0 \mathrm{~mm} / \mathrm{h})$ level, and mild hypoalbuminemia $(31.0 \mathrm{~g} / \mathrm{L})$. Stool routine revealed Leukocyte $++++/ \mathrm{HP}$, pus cell $++++/ \mathrm{HP}$, stool blood was positive. Amoeba cysts were found after repeated stool examinations, but no trophozoites. Blood cultures, HBV, CMV-DNA, TORCH-IgM, G/GM, TB-IGRA, parasite antibody were negative. The plasma biochemistry of liver and kidney functions were normal. A total of three colonoscopes and biopsies were performed for the patient, and the results showed multiple irregular ulcers in the whole colon (Figure 1). Colonic biopsies diagnosed Epstein-barr virus-associated lymphoproliferative disorder, but the sample was inadequate for definitive diagnosis. Bone marrow examination showed the proliferation of hematopoietic cells were active, mainly granulocytes, and immature granulocytes increased. Findings of CT images of chest and neck were normal. Contrast-enhanced CT scan of the whole abdomen revealed multi-segmental intestinal wall thickening and enhancement (Figure 2A). 18F-FDG PET/CT demonstrated increased FDG uptake in the whole colon, bone marrow and spleen (Figure 3).

Treatment of the patient was provided with anti-infective (moxifloxacin, rifaximin, metronidazole and imipenem, vancomycin, and cefperazone-sulbactam, tigecycline were given successively). However, he still had diarrhea and recurrent fever, the body temperature fluctuated at $39-40^{\circ} \mathrm{C}$. Blood cultures were still negative. No positive bacilli was found by acid fast staining and no DNA fragment of Mycobacterium tuberculosis

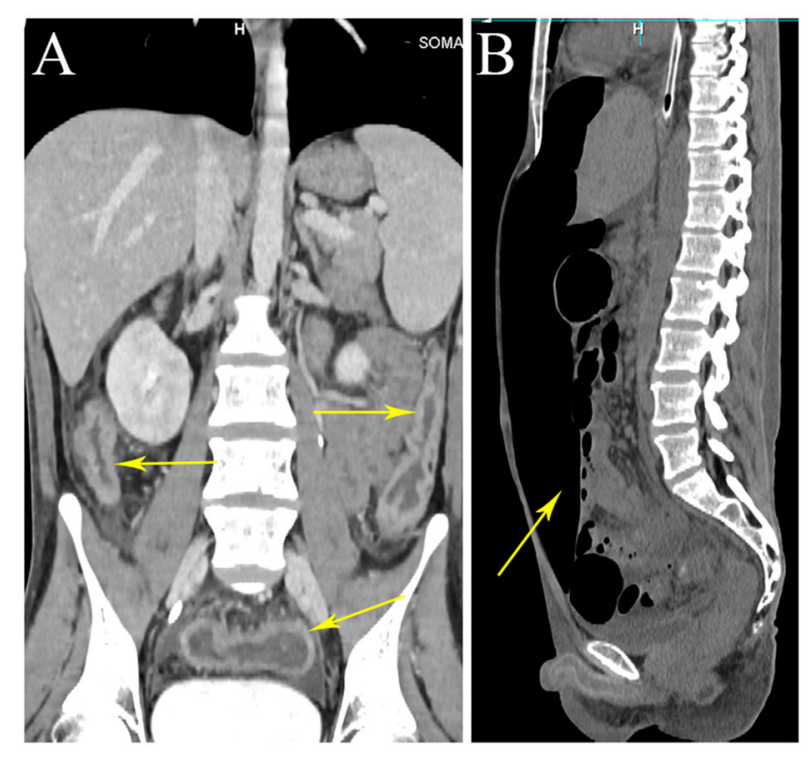

FIGURE 2 | Whole abdominal CT. CT scan showing wall thickening of the colon (arrows). CT scan showing a large amount of free gas in abdominal cavity (arrow). (A) Coronal view. (B) Sagittal view.

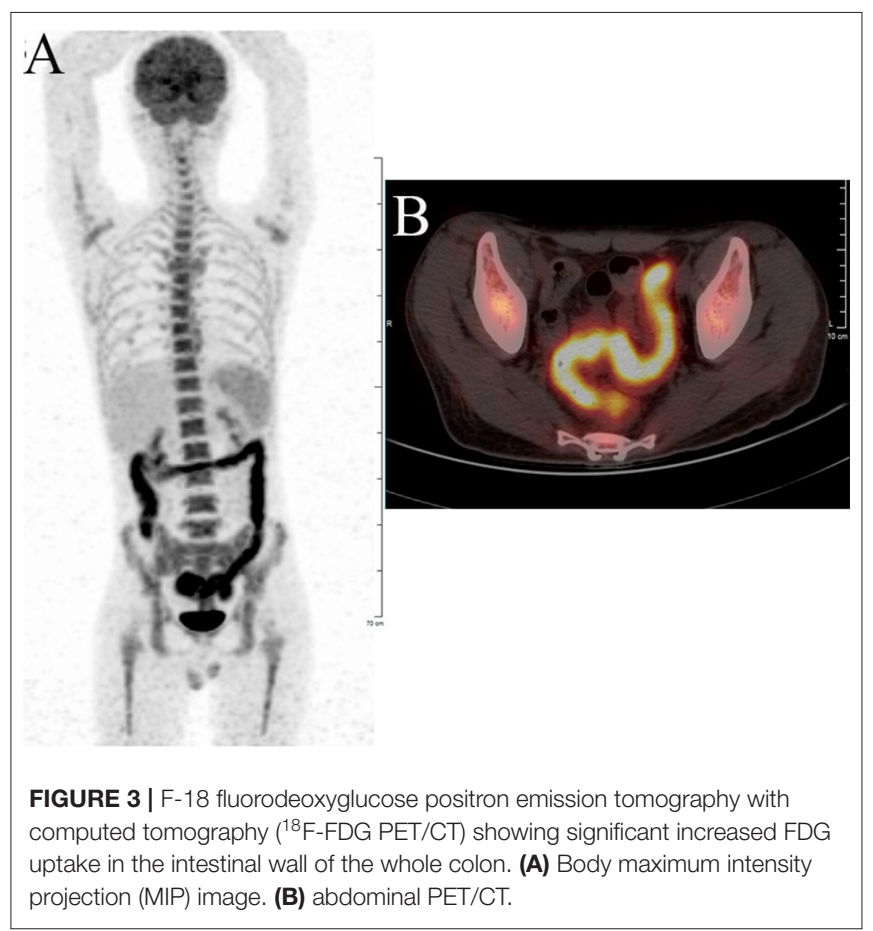

was found by qPCR. During the hospitalization, the patient developed a fierce abdominal pain, CT indicated gastrointestinal perforation (Figure 2B). An emergency surgery was performed. During surgery, it was found that there were two $0.5 \mathrm{~cm}$ breaks in the ileocecal junction, a $3 \mathrm{~cm}$ break in the descending colon, three perforation holes of varying sizes were seen in the sigmoid colon with a diameter of about $0.5-1 \mathrm{~cm}$, and three $0.5-4 \mathrm{~cm}$ 


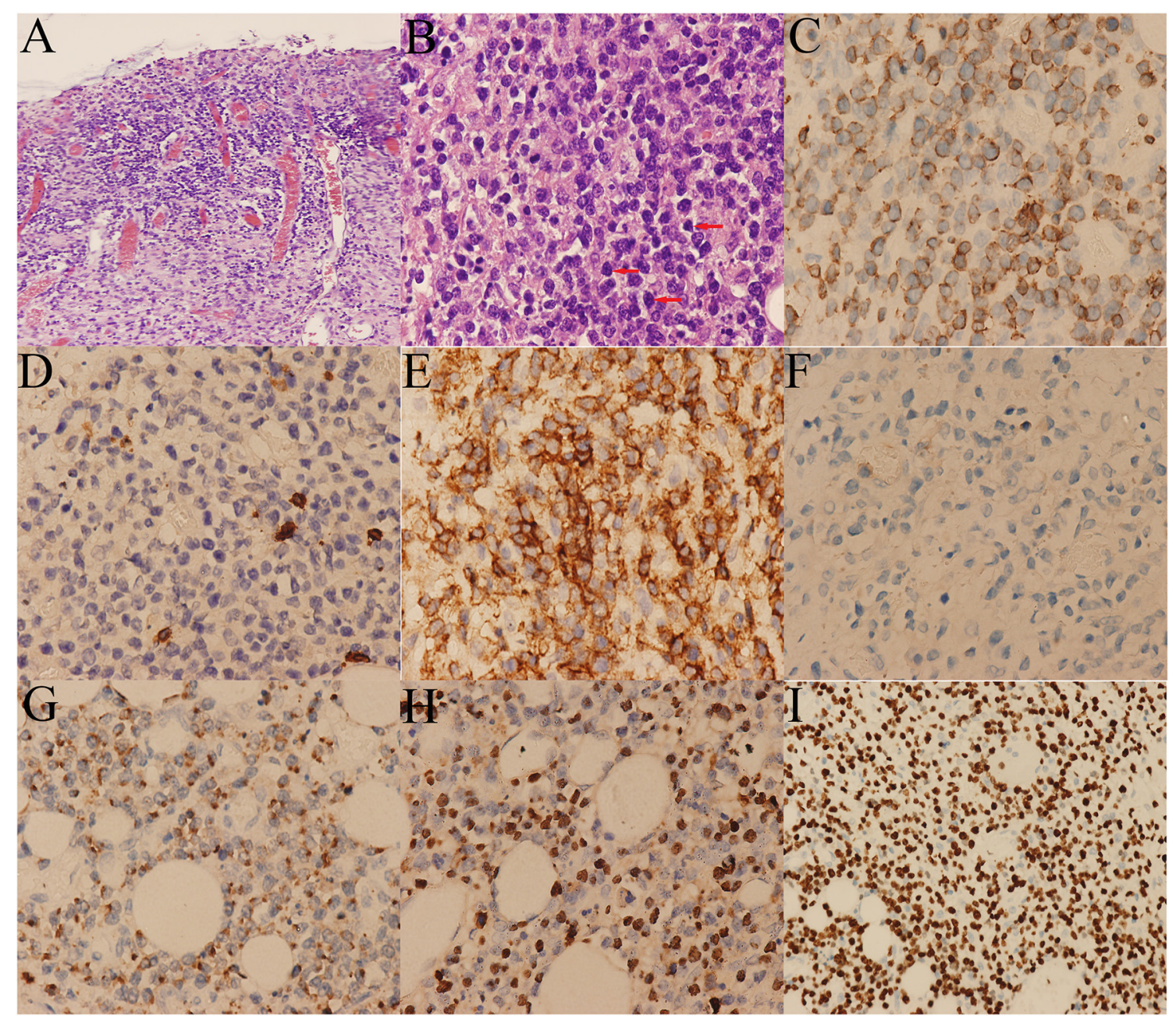

FIGURE 4 | Histological and immunohistochemical pictures of the lymphoma. (A) The tumor cells infiltrated the whole wall of the colon. (B) Diffusely infiltrating of medium-sized tumor cells with irregular nuclei (arrows). Immunohistochemical stains showing the tumor cells are positive for (C) CD3, (E) CD43, (G) GB, and (H) EBER, and negative for (D) CD5, (F) CD56. (I) The Ki-67 labeling index was around 60\%.

breaks in the upper rectal segment $3 \mathrm{~cm}$ from the peritoneal reflection. The intestinal wall around the breaks was edematous and congestive. He underwent total colectomy and enterostomy. ENKTL was diagnosed for pathological diagnosis of surgical samples. Histologically, the tumor cells were medium in size with irregular nuclei (Figure 4B). There were mixed inflammatory infiltrated mainly including lymphocytes and plasmacytes. The tumor cells infiltrated the whole wall of the intestinal wall with ulcer, necrosis (Figure 4A). Immunohistochemical staining showed that $\mathrm{CD} 3, \mathrm{CD} 2, \mathrm{CD} 43$, granzyme $\mathrm{B}$ (GB), TIA-1 were positive, while $\mathrm{CD} 20, \mathrm{CD} 5, \mathrm{CD} 7, \mathrm{CD} 4, \mathrm{CD} 8, \mathrm{CD} 56$ were negative (Figures 4B-G). CD30 was focally positive. The Ki-67 labeling index was 60\% (Figure 4I). EBV-encoded small RNA (EBER) analysis showed positive (Figure $\mathbf{4 H}$ ). Gene rearrangement test found the low amplification peak of TR gene.
After recovering from surgery, the patient was treated with two courses of etoposide $50 \mathrm{mg}$ and dexamethasone $5 \mathrm{mg}$ (ED) regimen. Gemcitabine was added on the third day of the second course of therapy. Two weeks later, PD-1 monoclonal antibody $100 \mathrm{mg}$ was used to replace ED regimen because his general condition and the expected chemotherapy tolerance were poor (A total of 3 times, each interval of 3 weeks). Fortunately, the patient was discharged the next day after the last treatment with PD-1 monoclonal antibody. By the time he was discharged from the hospital, his general condition improved significantly. PD-1 monoclonal antibody $100 \mathrm{mg}$ was used on day 23,56, 85 after discharged. To date, the patient has treated with a total of six courses of PD-1 monoclonal antibody. Eleven months follow-up was uneventful. 


\section{DISCUSSION}

Primary intestinal NK/T cell lymphoma (PIENKTL) is an extremely rare and invasive tumor. Most of the patients had a poor prognosis and the average survival period was only 2.83-9.5 months. The most common site of involvement of PIENKTL is the colon, followed by the jejunoileum and ileocecum. The prevalence is higher in the third decade of life (5-8). A small number of patients with intestinal NK/T cell lymphoma will have a complication of perforation, including the case we present. Perforation mechanism of the intesitinal wall is not well-known, we hypothesized that might be related to the infiltration of mesenteric vascular and serous. Currently, few studies with small sample sizes have been reported so little is known about its clinical characteristics. The most common clinical symptoms reported in the studies $(9,10)$ include abdominal pain, diarrhea, fever, and intestinal bleeding. Clinical manifestations of our case were consistent with reported in studies. Subsequently, we reviewed and summarized the clinical characteristics, pathological features, and treatment approach of reported cases of PIENKTL (Table 1).

The study of Jiang et al. (8) found that if the patients were operated on before perforation, there was an improved prognosis, whereas patients who underwent surgery after perforation had a similar prognosis to patients who underwent no surgery. This implies the importance of early diagnosis and operation before perforation of PIENKTL. In clinical practice, the presence of PIENKTL should be alerted if the following situations occur: moderate-to-high grade fever occurs recurrently, CT showes thickening of multi-segment intestinal wall and enhancement of enlarged lymph nodes of mesentery, colonoscopy showes multiple, irregular, and variable-sized deep ulcers $(23,24)$.

However, early diagnosis of PIENKTL is frequently diffcult. Most patients are definitely diagnosed only after surgical resection of following complications. PIENKTL is easily misdiagnosed as inflammatory bowel disease (IBD) clinically. We herein summarize several possible reasons for the misdiagnosis. The clinical manifestations, endoscopic features, and imaging findings of IBD are similar to PIENKTL and compared with PIENKTL, IBD is a more common disease. Histologically, features of IBD, including crypt abscesses, anomalies in structure or number of glands, gangliocyte hyperplasia and even non-caseating granulomas, can be found in some cases of PIENKTL (10). In addition, it is difficult to distinguish the atypical lymphoid cells from normal reactive lymphocytes, a large amount of inflammatory infiltrates may obscure the relatively small number of tumor cells. Atypical lymphoid cells are usually clustered deep in the submucosa or break through the serous membrane, but mucosa involvement is uncommon (5). Therefore, we can't make a diagnosis easily if intestinal malignant lymphoma is suspected with negative histological evidence. Repeat endoscopy combined with deep biopsies may increase the possibility of definitive pathological diagnosis. If necessary, an exploratory laparotomy can be considered in time for early diagnosis.
Pathologically, PIENKTL should be differentiated from the other intestinal $\mathrm{T}$ cell lymphomas, including enteropathy associated T-cell lymphoma (EATL), monomorphic epitheliotropic intestinal T-cell lymphoma (MEITL), and peripheral T-cell lymphoma, not otherwise specified (PTCL, NOS). EATL formerly thought to be composed of two subtypes known as type I and type II. Type I EATL is now simply classified as EATL. It is strongly associated with coeliac disease. Type II EATL has been renamed MEITL. It shows no definite association with coeliac disease (25). Histologically, necrosis, and ulcer can be observed in PIENKTL and EATL, while necrosis is rare in MEITL. The tumor cells can infiltrate full-thickness of the intestinal wall both in PIENKTL, EATL, and MEITL. Epithelial involvement is common in EATL and MEITL, but not in PIENKTL. The tumor cells of PIENKTL are usually small to medium in size. The neoplastic cells of EATL are medium to large in size with prominent nucleoli, and they can have an immunoblastic or anaplastic appearance $(6,25-$ 27). Most $\mathrm{T}$ cell and NK/T cell lymphomas have a common histological feature: irregular tumor cells of different shape or size mixed with inflammatory component. However, MEITL is an exception, for it shows with monotonous small tumor cells and few reactive cells. In addition, angiocentrity can usually be observed in PIENKTL and EATL, while it is absent in MEITL (6). Most MEITLs are positive for megakaryocyteassociated tyrosine kinase, which is diagnostically useful when expressed by $>80 \%$ of cells (25). In situ hybridization for EBER plays a key role in differential diagnosis, which is negative in EATL, MEITL, and PTCL, NOS cases while positive in PIENKTL cases (6). The diagnosis of PTCL, NOS is based on the exclusion of all the other $\mathrm{T}$ cell lymphomas. Furthermore, secondary involvement of the intestine by nodal $\mathrm{T}$ cell lymphoma requires exclusion $(6,25)$. A definitive diagnosis of PIENKTL depends on immunohistochemistry. Compared to other sites of involvement, there is no difference in the immunophenotype of intestinal NK/T cell lymphoma. The tumor tissues express CD3e, CD43, CD56, and cytotoxic molecules (such as TIA1 and GB). Nuclear labeling for in situ hybridization for EBER is positive and T-cell receptor gene rearrangement (9). CD56 is an NK cell marker, and the studies $(5,14)$ showed that the positive frequency of CD56 in PIENKTL was 8489.1\%. Although it can help diagnose the PIENKTL, it is not specific for NK/T cell lymphoma. Few patients were negative for CD56 and the case we report was rare with lacking of CD56 expression.

Appropriate treatment of PIENKTL is very important to improve the prognosis. However, a standard treatment strategy for PIENKTL has not yet been established. Kim's study (28) found that patients who underwent surgery plus chemotherapy showed a relatively better survival prognosis than those treated with chemotherapy alone. To date, there is no standard chemotherapeutic regimen for PIENKTL. In the previous studies $(8,14)$, the chemotherapy regimens of PIENKTL were varied. Chemotherapy with a DICE (dexamethasone, ifosfamide, cisplatin, and etoposide), CHOP (cyclophosphamide, doxorubicin, vincristine and prednisone) or L-asparaginase/pegasparginase-containing regimen was most often employed. So far, 
TABLE 1 | Summary of the published cases of primary intestinal NK/T cell lymphoma.

\begin{tabular}{|c|c|c|c|c|c|c|c|c|c|}
\hline References & Age & Sex & $\begin{array}{l}\text { Clinical } \\
\text { manifestations }\end{array}$ & Location & $\begin{array}{l}\text { Morphologic } \\
\text { features }\end{array}$ & Immunophenotype & ISH of EBER & Treatment & $\begin{array}{l}\text { OS } \\
\text { (median OS) }\end{array}$ \\
\hline Duan et al. (11) & 12 & M & $\begin{array}{l}\text { Abdominal pain, } \\
\text { fever }\end{array}$ & Colon & $\begin{array}{l}\text { Medium-sized atypical } \\
\text { lymphoid cells with } \\
\text { large areas of necrosis }\end{array}$ & $\begin{array}{l}\text { CD2+, CD3+, CD4+, } \\
\text { CD5+, CD8+, } \\
\text { sCD43+,CD56+, } \\
\text { TIA-1+, GB+, Ki-67: } \\
60 \%\end{array}$ & Positive & Surgery & Within 1 month \\
\hline Li et al. (12) & 40 & $\mathrm{~F}$ & Loose stools, fever & Colon & $\begin{array}{l}\text { Focal heterotypic } \\
\text { lymphocyte } \\
\text { infiltration?heterotypic } \\
\text { lymphocyte clusters }\end{array}$ & $\begin{array}{l}\text { CD2+, CD3+, CD5+, } \\
\text { CD20+, CD34+, } \\
\text { CD } 61+, \text { CD79 } \alpha \\
\text { TIA-1+, Ki-67: } 40 \%\end{array}$ & Positive & $\begin{array}{l}\text { Methylprednisolone } \\
\text { combined with } \\
\text { Podexan and a } \\
\text { salford enema }\end{array}$ & a few months \\
\hline Lookzadeh et al. (13) & 56 & M & $\begin{array}{l}\text { Fever, productive } \\
\text { cough, dyspnea, } \\
\text { Vomiting, chill }\end{array}$ & Terminal ileum & $\begin{array}{l}\text { Infiltration of } \\
\text { pleomorphic } \\
\text { neoplastic lymphoid } \\
\text { cells }\end{array}$ & $\begin{array}{l}\text { CD3+, CD8+, CD30+, } \\
\text { CD56+, LCA+, Ki-67: } \\
70 \%\end{array}$ & & Surgery & $\mathrm{N} / \mathrm{A}$ \\
\hline Yang et al. (9) & $15-72$ & $\begin{array}{l}\text { M: 9; } \\
F: 4\end{array}$ & $\begin{array}{l}\text { Abdominal pain, } \\
\text { gastrointestinal } \\
\text { bleeding, diarrhea, } \\
\text { fever }\end{array}$ & $\begin{array}{l}\text { Small intestine: 4; } \\
\text { large intestine: } 9\end{array}$ & $\begin{array}{l}\text {; The tumor cells were } \\
\text { predominantly } \\
\text { medium to small in } \\
\text { size }\end{array}$ & $\begin{array}{l}\mathrm{CD} 3 \varepsilon+, \mathrm{CD} 5+, \\
\text { CD56+, CD43+, } \\
\text { TIA-1+, GB+, The } \\
\text { Ki-67 index ranged } \\
\text { from } 30 \text { to } 70 \%\end{array}$ & Positive & $\begin{array}{l}\text { Surgery, } \\
\text { chemotherapy, } \\
\text { Surgery + } \\
\text { chemotherapy }\end{array}$ & 6 months \\
\hline Wang et al. (10) & $24-54$ & $\begin{array}{l}\text { M: 6; } \\
F: 6\end{array}$ & $\begin{array}{l}\text { Abdominal pain, } \\
\text { haematochezia, } \\
\text { diarrhea, weight } \\
\text { loss, fever }\end{array}$ & $\begin{array}{l}\text { ileal: 1; } \\
\text { ileocecum: 7; } \\
\text { colon: 9; rectum: } \\
5\end{array}$ & $\begin{array}{l}\text { Chronic } \\
\text { mucosal/submucosal } \\
\text { inflammatory infiltrates } \\
\text { with clusters of } \\
\text { medium- or } \\
\text { small-sized lymphoid } \\
\text { cells }\end{array}$ & $\begin{array}{l}\text { CD3 } \varepsilon+, \text { CD } 56+\text {, } \\
\text { TIA-1+, GB+, The } \\
\text { Ki-67 index ranged } \\
\text { from } 5 \text { to } 80 \%\end{array}$ & Positive & $\begin{array}{l}\text { Surgery, } \\
\text { chemotherapy, } \\
\text { Surgery + } \\
\text { chemotherapy }\end{array}$ & 6.3 months \\
\hline Tang et al. (6) & $15-85$ & $\begin{array}{l}\mathrm{M}: 14 ; \\
\mathrm{F}: 3\end{array}$ & $\begin{array}{l}\text { Abdominal pain, } \\
\text { haematochezia, } \\
\text { diarrhea }\end{array}$ & $\begin{array}{l}\text { Small intestine: 5; } \\
\text { ileocecum: 5; } \\
\text { colon: } 10\end{array}$ & $\begin{array}{l}\text { The tumor cells were } \\
\text { small }(23.5 \%) \text {, } \\
\text { medium to small } \\
(41.2 \%) \text { and medium } \\
(23.5 \%), \text { medium to } \\
\text { large }(11.8 \%) \text { in size }\end{array}$ & $\begin{array}{l}\text { CD8+, CD30+, } \\
\text { CD56+, TIA-1+, GB+ }\end{array}$ & Positive & $\begin{array}{l}\text { Surgery, } \\
\text { chemotherapy, } \\
\text { Surgery + } \\
\text { chemotherapy }\end{array}$ & 4.3 months \\
\hline Yu et al. (14) & $14-75$ & $\begin{array}{l}\text { M: } 37 \\
F: 18\end{array}$ & $\begin{array}{l}\text { Abdominal pain, } \\
\text { lower Gl bleeding } \\
\text { or fecal occult } \\
\text { blood, fever }\end{array}$ & $\begin{array}{l}\text { Small intestine: } \\
\text { 28; ileocecum: } \\
\text { 11; colon: 13; } \\
\text { different intestinal } \\
\text { segments: } 3\end{array}$ & $\begin{array}{l}\text { The atypical lymphoid } \\
\text { cells infiltrated, the } \\
\text { tumor cells were } \\
\text { I displayed a mixed } \\
\text { population of small, } \\
\text { medium to large } \\
\text { (43.6\%), small to } \\
\text { medium (32.7\%), } \\
\text { medium }(21.8 \%) \text {, } \\
\text { small }(1.8 \%) \text { in size }\end{array}$ & $\begin{array}{l}\text { CD2+, CD4+, CD5+, } \\
\text { CD7+, CD8+, CD30+, } \\
\text { CD56+, TIA-1+, GB+, } \\
\text { The Ki-67 index ranged } \\
\text { from } 50 \text { to } 90 \%\end{array}$ & Positive & $\begin{array}{l}\text { Surgery, } \\
\text { chemotherapy, } \\
\text { Surgery + } \\
\text { chemotherapy }\end{array}$ & 12.7 months \\
\hline Chen et al. (15) & 29 & M & $\begin{array}{l}\text { Abdominal pain, } \\
\text { diarrhea, } \\
\text { haematochezia, } \\
\text { fever }\end{array}$ & Small intestine & $\begin{array}{l}\text { The tumor cells were } \\
\text { large in size }\end{array}$ & CD56+, Ki-67: 10\% & Positive & $\begin{array}{l}\text { Surgery }+ \\
\text { chemotherapy }\end{array}$ & $20 d$ \\
\hline Fang et al. (7) & 24-68 & $\begin{array}{l}M: 7 \\
F: 3\end{array}$ & $\begin{array}{l}\text { Abdominal pain, } \\
\text { diarrhea, } \\
\text { haematochezia, } \\
\text { fever }\end{array}$ & Small intestine & $\begin{array}{l}\text { The tumor cells were } \\
\text { small (20\%), medium } \\
(20 \%) \text {, large }(50 \%) \text { in } \\
\text { size, or mixed medium } \\
\text { and large cells (10\%) }\end{array}$ & $\begin{array}{l}\text { CD2+, CD3+, CD30+, } \\
\text { CD56+, TIA-1+, GB+, } \\
\text { The Ki-67 index ranged } \\
\text { nfrom } 40 \text { to } 90 \%\end{array}$ & & $\begin{array}{l}\text { Surgery, } \\
\text { chemotherapy, } \\
\text { Surgery }+ \\
\text { chemotherapy }\end{array}$ & 9.5 months \\
\hline Aniwan et al. (16) & 29 & M & $\begin{array}{l}\text { Abdominal pain, } \\
\text { bloody diarrhea, } \\
\text { fever, weight loss }\end{array}$ & Colon & Small lymphoid cells & CD3+, CD56+ & Positive & Surgery & $\mathrm{N} / \mathrm{A}$ \\
\hline Zheng et al. (17) & 37 & M & $\begin{array}{l}\text { Abdominal pain, } \\
\text { bloody diarrhea, } \\
\text { fever }\end{array}$ & Colon & $\begin{array}{l}\text { Diffuse proliferation of } \\
\text { small and medium } \\
\text { sized atypical } \\
\text { lymphoid cells }\end{array}$ & $\mathrm{CD} 3 \varepsilon+, \mathrm{CD} 56+, \mathrm{GB}+$ & Positive & $\begin{array}{l}\text { Surgery }+ \\
\text { chemotherapy }\end{array}$ & 3 months \\
\hline Mahuad et al. (18) & 52 & M & Fever & Colon & $\begin{array}{l}\text { The tumor cells were } \\
\text { medium to large in } \\
\text { size }\end{array}$ & $\begin{array}{l}\text { CD2+, CD56+, } \\
\text { CD20+, GB+, Ki-67: } \\
40 \%\end{array}$ & Positive & $\begin{array}{l}\text { Surgery }+ \\
\text { chemotherapy }\end{array}$ & 2 months \\
\hline
\end{tabular}


TABLE 1 | Continued

\begin{tabular}{|c|c|c|c|c|c|c|c|c|c|}
\hline References & Age & Sex & $\begin{array}{l}\text { Clinical } \\
\text { manifestations }\end{array}$ & Location & $\begin{array}{l}\text { Morphologic } \\
\text { features }\end{array}$ & Immunophenotype & ISH of EBER & Treatment & $\begin{array}{l}\text { OS } \\
\text { (median OS) }\end{array}$ \\
\hline Zheng et al. (5) & $15-65$ & $\begin{array}{l}\text { M: 16; } \\
F: 9\end{array}$ & $\begin{array}{l}\text { Abdominal pain, } \\
\text { fever, weight loss, } \\
\text { diarrhea, } \\
\text { hematochezia }\end{array}$ & $\begin{array}{l}\text { Small intestine: } 8 \\
\text { ileocecum:8, } \\
\text { large intestine: } 1\end{array}$ & $\begin{array}{l}\text { 8; The tumor cells were } \\
\text { predominantly } \\
6 \text { medium or large in } \\
\text { size }\end{array}$ & $\begin{array}{l}\text { CD3+, CD56+, GB+, } \\
\text { The Ki- } 67 \text { index ranged } \\
\text { from } 50 \text { to } 80 \%\end{array}$ & Positive & $\begin{array}{l}\text { Surgery, } \\
\text { chemotherapy, } \\
\text { surgery + } \\
\text { chemotherapy }\end{array}$ & 7 months \\
\hline Panarelli et al. (19) & 37 & $\mathrm{~F}$ & Gl bleeding & Small intestine & $\begin{array}{l}\text { The tumor cells were } \\
\text { medium to large in } \\
\text { size }\end{array}$ & $\begin{array}{l}\mathrm{CD} 2+, \mathrm{CD} 3+, \mathrm{CD} 7+ \\
\mathrm{CD} 56+\end{array}$ & Positive & Surgery & $\mathrm{N} / \mathrm{A}$ \\
\hline $\begin{array}{l}\text { Wakabayashi et al. } \\
\text { (20) }\end{array}$ & 47 & M & $\begin{array}{l}\text { Abdominal pain, } \\
\text { bloody stool, fever }\end{array}$ & Small intestine & $\begin{array}{l}\text { Extensive diffuse } \\
\text { infiltration by atypical } \\
\text { lymphocytes in the } \\
\text { lamina propria prosae }\end{array}$ & $\mathrm{CD} 3+, \mathrm{GB}+$ & Positive & Surgery + BMT & 14 months \\
\hline Kakimoto et al. (21) & 73 & M & $\mathrm{N} / \mathrm{A}$ & Rectum & $\begin{array}{l}\text { The tumor cells were } \\
\text { large in size }\end{array}$ & CD3+, CD56+, GB+ & Positive & Surgery & $\mathrm{N} / \mathrm{A}$ \\
\hline Moubayed et al. (22) & $72 / 59$ & M & $\begin{array}{l}\text { Abdominal pain, } \\
\text { weight loss, } \\
\text { diarrhea }\end{array}$ & Terminal ileum & $\begin{array}{l}\text { The tumor cells were } \\
\text { large in size }\end{array}$ & $\begin{array}{l}\mathrm{CD} 2+, \mathrm{CD} 3+, \mathrm{CD} 7+ \\
\mathrm{CD} 8+, \mathrm{CD} 56+ \\
\mathrm{TIA}-1+\end{array}$ & Negative & $\begin{array}{l}\text { Surgery/surgery + } \\
\text { chemotherapy }\end{array}$ & $\mathrm{N} / \mathrm{A}$ \\
\hline
\end{tabular}

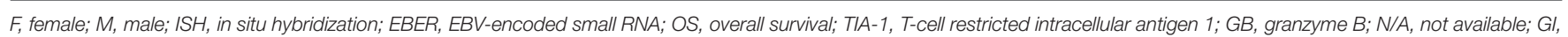
gastrointestinal; BMT, bone marrow transplant.

not much information is available on the role of radiotherapy in PIENKTL.

\section{CONCLUSIONS}

Early diagnosis of PIENKTL is extremely difficult, most patients are diagnosed at an advanced stage, resulting in a poor prognosis. It is difficult to obtain a definitive diagnosis by limited histopathological data offered by endoscopic biopsy, so repeat endoscopy combined with deep biopsy is necessary. When multiple biopsies still can't make a definite diagnosis but intestinal malignant lymphoma is highly suspected, exploratory laparotomy should be performed, so as not to delay the diagnosis.

\section{DATA AVAILABILITY STATEMENT}

The original contributions presented in the study are included in the article/supplementary material, further inquiries can be directed to the corresponding author.

\section{REFERENCES}

1. Suzuki R, Suzumiya J, Yamaguchi M, Nakamura S, Kameoka J, Kojima $\mathrm{H}$, et al. Prognostic factors for mature natural killer (NK) cell neoplasms: aggressive NK cell leukemia and extranodal NK cell lymphoma, nasal type. Ann Oncol. (2010) 5:1032-40. doi: 10.1093/annonc/ mdp418

2. de MS, Hue SS, Jeyasekharan AD. Molecular pathogenic pathways in extranodal NK/T cell lymphoma. J Hematol Oncol. (2019) 12:33. doi: 10.1186/s13045-019-0716-7

3. Wong MT, Eu KW. Primary colorectal lymphomas. Colorectal Dis. (2006) 7:586-91. doi: 10.1111/j.1463-1318.2006.01021.x

4. Cho MJ, Ha CS, Allen PK, Fuller LM, Cabanillas F, Cox JD. Primary non-Hodgkin lymphoma of the large bowel. Radiology. (1997) 5:5359. doi: 10.1148/radiology.205.2.9356641

\section{ETHICS STATEMENT}

Written informed consent was obtained from the individual(s) for the publication of any potentially identifiable images or data included in this article.

\section{AUTHOR CONTRIBUTIONS}

BW designed the report. YZ wrote the paper. WL performed the histopathological examination of the tumors and provided the pictures of tumor pathology. XZ provided and analyzed the pictures of PET/CT. All authors read and approved the final manuscript.

\section{ACKNOWLEDGMENTS}

The authors thank the patient who kindly agreed to provide them with the data used in this case. cell lymphoma: a clinicopathologic study of 25 Chinese cases. Arch Iran Med. (2012) 15:36-42. doi: 012151/aim.0011

6. Tang XF, Yang L, Duan S, Guo H, Guo QN. Intestinal T-cell and NK/T-cell lymphomas: a clinicopathological study of 27 Chinese patients. Ann Diagn Pathol. (2018) 37:107-17. doi: 10.1016/j.anndiagpath.2018.10.004

7. Fang JC, Xia ZX, Wang CN, Li Z. Clinicopathologic and immunophenotypic features of primary intestinal extranodal NK/T-cell lymphoma, nasal type. Int J Surg Pathol. (2015) 23:609. doi: 10.1177/1066896915595863

8. Jiang $M$, Chen X, Yi Z, Zhang X, Zhang B, Luo F, et al. Prognostic characteristics of gastrointestinal tract NK/T-Cell lymphoma: an analysis of 47 patients in China. J Clin Gastroenterol. (2013) 47:e74-9. doi: 10.1097/MCG.0b013e31829e444f

9. Yang L, Tang X, Peng X, Qian D, Guo Q, Guo H. Clinical characteristics of primary intestinal NK/T cell lymphoma, nasal type: 
case series and review of the literature. Pathol Res Pract. (2018) 214:1081-6. doi: 10.1016/j.prp.2018.05.013

10. Wang Z, Zhang W, Luo C, Zhu M, Zhen Y, Mu J, et al. Primary intestinal Epstein-Barr virus-associated natural killer/T-cell lymphoproliferative disorder: a disease mimicking inflammatory bowel disease. J Crohns Colitis. (2018) 12:896-904. doi: 10.1093/ecco-jcc/jjy043

11. Duan Y, Huang J, Haybaeck J, Yang Z. Primary extranodal natural Killer/Tcell lymphoma in a child in the colon: a case report. Medicine. (2021) 100:e24232. doi: 10.1097/MD.0000000000024232

12. Li H, Lyu W. Intestinal NK/T cell lymphoma: a case report. World J Gastroenterol. (2020) 26:3989-97. doi: 10.3748/wjg.v26.i27.3989

13. Lookzadeh S, Pourabdollah TM, Jamaati H, Rezaei M, Marashian M. Primary gastrointestinal involvement in a case of extranodal-extranasal natural killer T cell lymphoma. Tanaffos. (2020) 19:74-8.

14. Yu BH, Shui RH, Sheng WQ, Wang CF, Lu HF, Zhou XY, et al. Primary intestinal extranodal natural killer/T-cell lymphoma, nasal type: a comprehensive clinicopathological analysis of 55 cases. PLoS ONE. (2016) 11:e0161831. doi: 10.1371/journal.pone.0161831

15. Chen H, Zhang Y, Jiang Z, Zhou W, Cao Q. A case report of NK-Cell lymphoproliferative disease with a wide involvement of digestive tract develop into Epstein-Barr virus associated $\mathrm{NK} / \mathrm{T}$ cell lymphoma in an immunocompetent patient. Medicine. (2016) 95:e3176. doi: 10.1097/MD.00000000000 03176

16. Aniwan S, Rerknimitr R, Wisedopas N, Kullavanijaya P. Colonic NK/T-cell lymphoma mimicking Crohn's disease. Endoscopy. (2014) 46(Suppl. 1):E3123. doi: 10.1055/s-0034-1377220

17. Zheng S, Xu H, Ouyang Q, Xue L, Zhang Y, Cui D. A case of rapid growing colonic NK/T cell lymphoma complicated by Crohn's disease. Chin J Cancer Res. (2013) 25:119-23. doi: 10.3978/j.issn.1000-9604.2012.12.06

18. Mahuad CV, Bilbao ER, Garate GM, de Los Angeles Vicente Reparaz M, Del Olmo M, Casali CE, et al. Primary NK/T cell lymphoma nasal type of the colon. Rare Tumors. (2013) 5:e9. doi: 10.4081/rt.2013.e9

19. Panarelli NC, Furman RR, Wang YL, Elstrom R, Cohen JA, Chadburn A. NK/T cell non-Hodgkin lymphoma in a HIV-positive patient. J Hematop. (2010) 3:35-40. doi: 10.1007/s12308-010-0057-5

20. Wakabayashi S, Arai A, Oshikawa G, Araki A, Watanabe M, Uchida N, et al. Extranodal NK/T cell lymphoma, nasal type, of the small intestine diagnosed by double-balloon endoscopy. Int J Hematol. (2009) 90:60510. doi: 10.1007/s12185-009-0438-7

21. Kakimoto $K$, Inoue $T$, Nishikawa $T$, Ishida $K$, Kawakami $K$, Kuramoto $\mathrm{T}$, et al. Primary CD56+ NK/T-cell lymphoma of the rectum accompanied with refractory ulcerative colitis. J Gastroenterol. (2008) 43:576-80. doi: 10.1007/s00535-008-2192-7

22. Moubayed P, Leithauser F, Binder T, Uppenkamp M, Feller AC. Two cases of primary malignant NK/T-cell lymphoma in the small intestine following an aggressive clinical course: morphological, immunohistochemical, and molecular analysis. Leuk Lymphoma. (2007) 48:1451-5. doi: 10.1080/104281907013 87013

23. Kim JH, Lee JH, Lee J, Oh SO, Chang DK, Rhee PL, et al. Primary NK-/T-cell Lymphoma of the gastrointestinal tract: clinical characteristics and endoscopic findings. Endoscopy. (2007) 39:156-60. doi: 10.1055/s-2006-945114

24. Qi YG, Fang ZH, Huang Y. Analysis of computed tomography and pathological observations of non-Hodgkin lymphomas with peritoneal, omental and mesenteric involvement. Exp Ther Med. (2015) 9:8914. doi: 10.3892/etm.2015.2210

25. van VC, Spagnolo DV. T- and NK-cell lymphoproliferative disorders of the gastrointestinal tract: review and update. Pathology. (2020) 52:12841. doi: 10.1016/j.pathol.2019.10.001

26. Soderquist CR, Bhagat G. Gastrointestinal T- and NK-cell lymphomas and indolent lymphoproliferative disorders. Semin. Diagn. Pathol. (2020) 37:1123. doi: 10.1053/j.semdp.2019.08.001

27. Yi JH, Lee GW, Do YR, Jung HR, Hong JY, Yoon DH, et al. Multicenter retrospective analysis of the clinicopathologic features of monomorphic epitheliotropic intestinal T-cell lymphoma. Ann. Hematol. (2019) 98:254150. doi: 10.1007/s00277-019-03791-y

28. Kim SJ, Jung HA, Chuang SS, Hong H, Guo C, Cao J, et al. Extranodal natural killer/T-cell lymphoma involving the gastrointestinal tract: analysis of clinical features and outcomes from the asia lymphoma study group. J Hematol Oncol. (2013) 6:86. doi: 10.1186/1756-8722-6-86

Conflict of Interest: The authors declare that the research was conducted in the absence of any commercial or financial relationships that could be construed as a potential conflict of interest.

Copyright (c) 2021 Zhang, Liu, Zhang and Wu. This is an open-access article distributed under the terms of the Creative Commons Attribution License (CC BY). The use, distribution or reproduction in other forums is permitted, provided the original author(s) and the copyright owner(s) are credited and that the original publication in this journal is cited, in accordance with accepted academic practice. No use, distribution or reproduction is permitted which does not comply with these terms. 